\title{
The Challenges in Requirements and Qualification for Selangor Private Tahfiz Educational Institution Teachers
}

\author{
Azizi Umar, Mohd Mahan Awang, Nazri Muslim, Wan Zulkifli Wan Hassan \\ and Mohamad Haiz Muhammad Haneefa
}

To Link this Article: http://dx.doi.org/10.6007/IJARBSS/v11-i6/10169

DOI:10.6007/IJARBSS/v11-i6/10169

Received: 07 April 2021, Revised: 10 May 2021, Accepted: 26 May 2021

Published Online: 12 June 2021

In-Text Citation: (Umar et al., 2021)

To Cite this Article: Umar, A., Awang, M. M., Muslim, N., Hassan, W. Z. W., \& Haneefa, M. H. M. (2021). The Challenges in Requirements and Qualification for Selangor Private Tahfiz Educational Institution Teachers. International Journal of Academic Research in Business and Social Sciences, 11(6), 380-391.

Copyright: (c) 2021 The Author(s)

Published by Human Resource Management Academic Research Society (www.hrmars.com)

This article is published under the Creative Commons Attribution (CC BY 4.0) license. Anyone may reproduce, distribute, translate and create derivative works of this article (for both commercial and non-commercial purposes), subject to full attribution to the original publication and authors. The full terms of this license may be seen at: http://creativecommons.org/licences/by/4.0/legalcode

Vol. 11, No. 6, 2021, Pg. 380 - 391

Full Terms \& Conditions of access and use can be found at http://hrmars.com/index.php/pages/detail/publication-ethics 


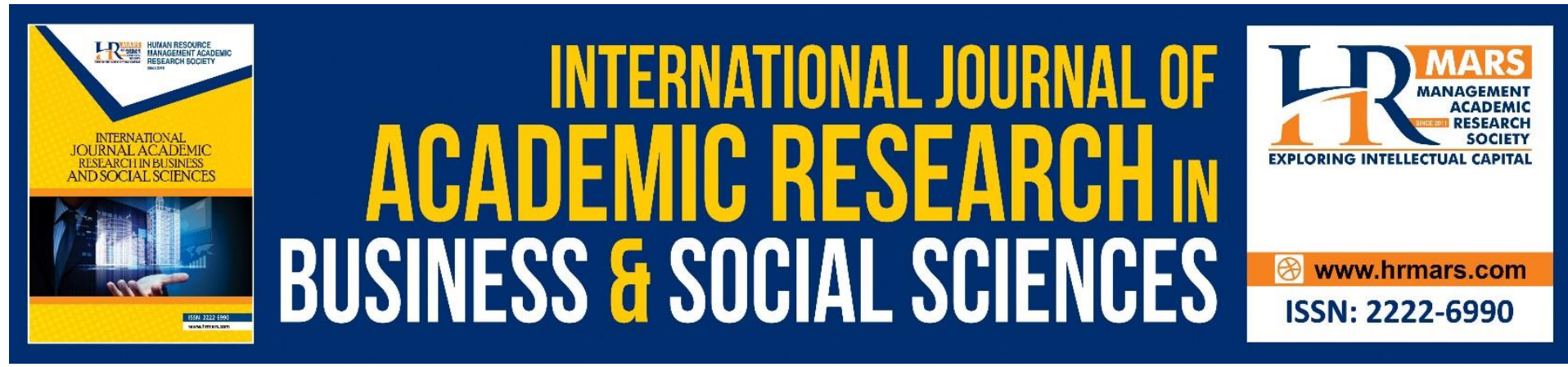

\title{
The Challenges in Requirements and Qualification for Selangor Private Tahfiz Educational Institution Teachers
}

\author{
Azizi Umar ${ }^{1}$, Mohd Mahan Awang², Nazri Muslim¹, Wan Zulkifli \\ Wan Hassan ${ }^{1}$ and Mohamad Haiz Muhammad Haneefa ${ }^{3}$ \\ ${ }^{1}$ School of Liberal Studies, Universiti Kebangsaan Malaysia, 43600 Bangi, Selangor, Malaysia, \\ ${ }^{2}$ Faculty of Education, Universiti Kebangsaan Malaysia, 43600 Bangi, Selangor, Malaysia, \\ ${ }^{3}$ Selangor Tahfiz Institute Association, Selangor, Malaysia \\ Email: nazrim@ukm.edu.my
}

\begin{abstract}
Requirements and qualifications for any work field play an important role in the sustainability of an organisation including teaching services whether it is a governmental or private organisation. The Requirements and Qualification for Selangor Private Tahfiz Educational Institution Teachers is important to make sure private tahfiz institution become more competitive and relevant. This research aims to study the challenges faced for requirements and qualifications for a private maahad tahfiz in Selangor. This research uses the interview method done with the school board activist who has the experience in tahfiz educational institution management. The documentation method is also used through related fields of organizational management, which are responsible for the teachers including documents from other related organizations. The study found that the approval status for teachers are mainly still low, a dilemma the school needs to fulfill for the requirements of the teachers and government in offering curriculum. Offering this curriculum causes the maahad party difficulties in balancing the requirements of the teaching field with the teacher's study field due to outside factors presented by educational institutions and universities. A pay rate disproportionate to the qualifications of the teacher also pose as a major challenge to the maahad management. This challenge exists due to the imbalance between the true human resources supply and demand in addition to the poor strategic cooperation system between the government and the private parties. In Malaysia, the flexible democratic educational system leans specifically towards non-governmental educational entities. The national educational system and the non-national education system do not seem to support each other. A strategic cooperation mechanism should be developed to solve a majority of the abovementioned problems so that all involved entities may be on the same goal path to ensure the success of future generations of students. For further research, should focus on private Tahfiz Institution in Malaysia.
\end{abstract}

Keywords: Teacher Requirements, Teachers Qualifications, Private Maahad Tahfiz 


\section{Introduction}

The current education system is in a constant in a state of change in line with environmental requirements. The success of an organisation can be achieved if their main goals are turned into their main focus and have a sensitive attitude towards the service process they provide. The main model activators are the workers who become the pulse of the organisation, including the educational service such as educators. However, the roles of teachers are different from other services as their products are students. Educational organizational services will of course need require necessary qualifications suited to the role as stated by the employer. Qualification in a particular field plays an important role in the sustainability of an organisation such as non-governmental educational institution.

As with other service managements, the educational sector calls for qualifications and requirements for potential teachers to meet the standards of need of change in an educational environment. To sire quality teachers is not an easy task. It must begin from their own qualifications to teach which will then be further accessorized with teacher's qualifications in line with the current educational knowledge requirements. When this accepted teaching education receives certification from any recognized evaluation body, it can guarantee a sustainable quality education in any field needed.

\section{Research Objective}

To clarify the main objective of this research, the author has outlined the objectives as follows:

i. To be acquainted with the level of qualification of teachers and wage payment to the teachers in private Maahad Tahfiz in Selangor

ii. Identify the commitment needed to fulfill a teacher's requirements based on the curriculum field offered and the teacher's teaching field in the same institute

This research is conducted with the aim to learn about the requirements and qualifications of teachers in private Maahad Tahfiz in Selangor and the professional competitiveness in choosing their career.

\section{Research Problems}

The effects of universal globalization increasingly challenge the demands of the community to emphasize on education and dynamic knowledge especially for individual educators. The need to rise to these challenges includes the need for educational knowledge, sociological context, economical, psychological, as well as education methods. This educational requirement context refers to the professional aim of "out-to-be" and level of service competence. Requirements such as benefits of learning, known methods and those still yet to be learned are flexible according to the teaching goal whether it is personal or professional (Sava, 2012).

In Malaysia, tahfiz education instruction is among the growing fields of Islamic studies. Every state and district has identified his or her own madrasah tahfiz whether it is under the management of the government, agency, or private. In addition, the existence of madrasah tahfiz, which is gaining popularity among the community, adds to its development. This phenomenon proves that parents are starting to realize the positives of having their children educated in an environment and education that is centered on the Al-Quran (Abdullah \& Safazilah, 2016). However, this expansion gives rise to other issues seeing that the rate of job 
offers as educator are also increasing which are; the challenges of qualification and requirements of teachers as well as educators based in maahad tahfiz.

Based on the problems above, this article aims to delve into the requirements and qualifications of Maahad Tahfiz teachers in the state of Selangor and the professional competitiveness in choosing their career.

\section{Education Level Requirements and Qualifications Challenges}

A qualification is defined as specific abilities, competencies, or transparency. Teachers bring the meaning of someone who teaches, an educator or a caretaker (pengasuh). It is understood that a teacher is someone who is competent and has special qualifications to teach and educate.

When the community leans towards a higher tahfiz education, it means that there is a rising need for tahfiz teachers as well. There is an abundance of positions as teaching staff and tahfiz teachers that have been on offer to fulfill this need. This is a golden opportunity for graduates who are looking for a position. These are the people who will fill the vacancies and requirements of the position. If the requirement of a tahfiz teacher has been filled and balanced, it brings forth to other issues whereby a number of the teachers who have been appointed are in fact unqualified as maahad tahfiz teachers and only have the necessary qualifications to be regular teachers. A number of them do not have the specific professional education however they are able to fulfill their duty and the responsibility of educating.

The issue of teachers appointed without the necessary qualifications can be found in any given private maahad tahfiz. This problem begins from the commencement of the madrasah. This predicament is created when a small group of founders who open schools or madrasah tahfiz with the intention of creating new job opportunities. One of the effects is job opportunities by government agencies or the equivalent. From a different perspective, educational responsibilities should be under the management and responsibility of governmental agencies or institutions approved by the government. In this case, the community has taken over the role with the aim of helping to lighten the responsibility of the government agency in the matters of education.

Following that, there are other side issues such as the imbalance of the teachers market. The needs or requests by teachers are exorbitant while an offer for the teacher, or simply said, the total of qualified teachers is paltry. The accelerated growth of maahad tahfiz has given a huge impact on the required rates of tahfiz teachers to fulfill the current requests of the community that are seen to be more open to receive tahfiz education. At this point in time, tahfiz institutions involved will increase the demand for teachers to accommodate the current requirements. In terms of economic stability from a labour or worker market, the equilibrium point of the teacher market can only be achieved when the quantity of required or needed teachers is the same as the quantity of the teachers on offer or those who are qualified at a certain pay rate.

Pay rates are a crucial matter in any given field or job offering. We can see this because of the relationship between the pay rate and the labour supply is a positive parallel. When the pay rate is high, therefore the labour supply on offer also rises, and vice versa. Wage rates are the key to a balance in the labour market. Just as mentioned, the equilibrium point of the teacher market can only be achieved when the amount of teachers in demand or needed is 
the same as the amount of teachers on offer or those who are qualified at a certain pay rate. Salary payment rate in schools or private madrasah can be higher from a madrasah owned by others leading to a number the graduates to opt to be teachers there even though they lack the necessary qualifications to carry the educational responsibilities. Employers receive them with the aim to fulfill a teaching requirement within their institutions or maahad tahfiz.

\section{Methodology}

This research is conducted by using a mixed method design and qualitative field studies. The primary qualitative data for this research was obtained through field interviews, literature review, and document analysis.

\section{i. Interview method.}

This research was implemented by selecting seven private maahad tahfiz educational activists around the state of Selangor as a research organisation including several teachers from chosen maahad as community study. The research data obtained was in a qualitative from which was then analyzed using descriptive analysis method and inference.

\section{ii. Document analysis}

Overall, this research used the analytic data collection method to strengthen the data. This method helped the author to some extent to be more critical when obtaining the correct information. To study and understand each term, the themes, and discussion related to the research, the author analyzed documents obtained from primary and secondary sources. These documents were mostly obtained in the form of print material whether it was through past scholarly studies, websites from the organizations involved, official government documents, and management documents from the schools related to this study.

\section{ii. Literature review}

Through this secondary source method, the author scrutinized past researches related to the issues and problems of this research. The aim is to strengthen the research information and data obtained. Only research that met the requirements and limitations of this research was used as reference to ensure the issues and problems discussed are still relevant to the main objective of this research.

Choosing the state of Selangor for this research was done as this state accommodates the highest number of maahad tahfiz in this country in a multitude of shapes and categories from the viewpoints of private ownership, curriculum offered, and a combination of both. Selangor is also a part of Klang Valley, which is now the most advanced and densely populated area in Malaysia. According to records in 2020, registered and unregistered Maahad Tahfiz schools in this country stands at 1,470 (Saleh, 2020). The total number of tahfiz schools around Selangor that are registered with the Selangor Islamic Religion Department is estimated at around 348 institutions with a total number of appointed teachers at 3,278 teachers and over 20,000 registered students. On the other hand, data obtained from the Selangor Tahfiz Institute Association (Persatuan Institut Tahfiz Al-Quran Selangor, or PITAS), records the number of tahfiz schools in Selangor as over 450 schools. This total includes state-owned maahad tahfiz and schools that have yet to register. Based on the total stated, the total number of tahfiz in Selangor accounts for almost $30 \%$ of the entire total of maahad tahfiz in this country. 


\section{Findings and Discussion}

The findings from this research discusses on four main events, namely the graduation rate for teacher education, the challenge in fulfilling the teacher's education based on the offered curriculum, the imbalance in the requirements of the teaching field with the field of teacher's teaching, and the minimum salary rate.

\section{Graduation Level and Teacher Education}

Based on discussions with individuals with authority in a maahad tahfiz institution, teachers who are degree graduates is estimated at around $10-20 \%$, diploma graduates at $20-30 \%$, while the remainder hold a tahfiz certificate or equivalent. Certificate categorization is divided into three types that are syahadah certificate, end-of-school certificate, and Sijil Pelajaran Malaysia (SPM). End-of-school certificate here means a certificate of completion for Al-Quran memorization obtained in school. However, a number of schools do not take into account SPM certificates as the Al-Quran memorization certificate is prioritized. In general, teachers teaching in maahad tahfiz are only certificate and diploma graduates. For those with degrees, they do not usually last long in a school as they tend to receive better offers.

Interview results from selected informants estimates $40 \%$ of appointed teachers are graduates with tahfiz certificate and other equivalent certificates, 30\% are diploma holders. An additional $25 \%$ are degree holders. Percentage for degree holders will rise if the school offers academic curriculum. In approximately 5\% from all tahfiz in Selangor, teachers receive formal teaching education such as a diploma in education specially offered by private sectors.

According to Dunlap and Frank (1996), all teachers require a set of instructional skill in order to maximize their teaching results. Parallel with Richardson (2008), this skill set has become the main policy for the ministry to organize teaching matters such as teacher education, teaching qualifications, teacher appointment, training, and professional development for teachers.

Malcolm Knowles, as quoted by Mazmanian (1977), explained that teaching requirements is something that should be learned by certain individuals for the benefit of themselves, the organisation, or the community and it should be restricted by the level of competence and performance efficacy just as how it is described by the individual, organisation, or the community. The individual's education here refers to a teacher.

A teacher considered to be qualified, skilled, and knowledgeable in their profession must make strive to meet the dimensions of the teaching career (Siraj \& Ibrahim, 2012). An effective teacher must:

i. Possess the necessary qualifications and have lofty ambitions as a professional student for the sake of the learning of their students.

ii. Possess a professional spirit and competent values measured through experience and continuous teaching

iii. Possess high levels of skills, in-depth knowledge, teamwork spirit, and competitiveness

iv. Possess a positive personality as well as able to master and apply knowledge development and pedagogy in every teaching context

However in the context of tahfiz teachers, the most important characteristic is to have virtuous morals, able to be an example to the students, and have high murabbi traits. There are also those whose skills and knowledge qualifies them but are not appointed as they do 
not possess the certificate that enables them to be qualified to be appointed as a teacher especially in the field of Islamic education and tahfiz.

In rising to the challenges of current education, the education field is one of the most valuable experience for a student. This will give impact to human capital and the human development for the nation's future. Therefore, a teacher's qualification is highly important in influencing the tahfiz education process for the coming generations. The rate of qualifications for teachers based on available qualifications, shows that it does not describe the process of educational importance outcomes in tahfiz education.

\section{Cabaran memenuhi keperluan guru mengikut penawaran kurikulum}

In curriculum offerings in Maahad Tahfiz, they offer diniah curriculums or academics as additional curriculums other than tahfiz subjects. Maahad offering only tahfiz education is estimated at only $40 \%$. Offering tahfiz and diniah only is at $25 \%$, while maahad offering all three curriculums of tahfiz, diniah, and academics is at $20 \%$ and this rate is seeing an increase due to the call of needs from parents and suggestions from the local state religious authorities. On the other hand, integrated Maahad tahfiz that offers full academics with UPSR or PT3 examinations as well as SPM stands at 15\%, accounting for 31 maahad only.

Starting in 2020, Selangor Islamic Religion Department or JAIS with the cooperation from PITAS created a new curriculum, the Moderated Tahfiz Curriculum that makes it compulsory for all maahad tahfiz in Selangor to offer this curriculum starting in the year 2022. So far, 42 maahad tahfiz have been identified as pilot projects to evaluate the effectiveness of this curriculum and its evaluation. Subjects offered are Bahasa Malaysia, English, Arab Language, Mathematics, Fardhu Ain, Tajwid, and Manners to Al-Quran with a total for 7 hours of weekly learning with no less than 40 hours of Tahfiz instructions in one week. History and Science subjects will be introduced in the fourth and fifth years. Continuous assessment will be introduced without any form of examinations. Co-curriculum will be applied alongside the PITAS module for five years to polish the students' talents in public speaking, leadership, and entrepreneurship.

There are approximately 20-30\% Maahad tahfiz that use tahfiz and religious curriculum without academics. In the shortage of time in offering the curriculum, there is also an educational system called 'turath' which is also offered in a few schools, however the total is miniscule at $5 \%$. The researcher did not focus on the 'turath' curriculum as it is also a part of the diniah curriculum. It was introduced to solidify the contents of the ready diniah education. Turath subjects are core subjects, which are usually taught in hut institutions.

However, there is not a single school that is recorded in the integrated tahfiz and academic curriculum education category. This will pose some problems of imbalance between the load of teaching and the teaching qualifications whereby it indirectly created a gap between the burden of teaching between tahfiz, diniah, and academic teachers. This is due to the teaching process that directly depends on the burden of offering an integrated curriculum in any given school.

For tahfiz field of study, there is still confusion towards the difference between diniah and tahfiz. It is similar but not identical. Just as with other fields, the tahfiz education field, too, requires the skill and abilities of a trained teacher. From a ratio point of view, it is also different from regular teachers whereby the ratio of tahfiz teachers and students are 1:10 (one tahfiz teacher to 10 students. Generally, the needs of one teacher can occur between 10-12 students. However the approximation of the total rate can change if there is a maahad that offers diniah or academic curriculum. 
One of the main criteria which has become a necessity of professionalism in Maahad Tahfiz is that the teachers possess a high level of knowledge integration, multi-tasking and versatile, empathizing with human education, and anti-materialistic. There are a few schools that has enforced teachers teaching more than two fields which are academic and diniah. Some isolated cases exist whereby the teachers teach three fields at once, which are tahfiz, diniah, and academic. A burden in mastering the vastness of knowledge is the most challenging even if the spirit of knowledge integration is sky-high.

The implementation of this requirement requires two things, which are initial needs analysis to identify the student's level of education, their experience, content suitability, student's ability, and student's needs during the course as well as the ways to handle the needs of the students during the course of learning.

Offering three types of curriculum for the student's learning in maahad tahfiz is the main dilemma faced when reaching for a suitable integrated education philosophy in accordance with Islamic teachings with the demands of current and parental requirements. This problem can only be solved by the parties who provide the education that has solid financial stability whether is from the government of from the parents' own pockets.

\section{Imbalance in teaching needs with teachers' field of study}

Maahad Tahfiz also faces with tahfiz graduate teachers who do not have the ability to teach religious studies or diniah subjects. They are only able to master the memorization techniques even though a tahfiz needs is only a part of the needed qualifications. What more if there are offers of academic subjects. When we appoint a qualified teacher who is able to teach Diniah and academic subjects, however they find it difficult to teach Tahfiz subjects. If maahad tahfiz offers academic subjects, it could be seen as an added burden from a costing aspect specifically in the aspect of teacher requirements.

The requirements in education specifically in youth self-development can be created or influenced by provisions or requirements of current education. The level of education requirement differs from each individual according to his or her field and profession. The same goes with teachers. These requirements should be defined and be flexible according to progress.

i. Social needs are needed when students are at the stage of comparing themselves to their classmates or everyday environment.

ii. Requirements related to existing content knowledge as a reaction to new information presented.

iii. In the context of teaching-learning, a suitable method should be used when taking into account the needs of current interests.

Research by Bukhori et.al (2015) indicated that conflict when choosing a future career in one's life begins early on when choosing a course of study. This is evident in when $81 \%$ of his research respondents admit that they chose a career path based on future job opportunity expectations. Supporting said data, the researcher then quoted a statement by Noh, M. (2002) which emphasized career choosing as a the most important process in an individual's life especially when venturing into the workforce as the reality is that a career is the measure of future, status, life worth, and personality.

Even though there is no guarantee of a clear-cut career in the chosen education field, public and private university graduates everywhere including students holding a tahfiz certificate still choose to be in the education industry for the sake of career continuity and 
their future. One of the factors is due to the qualifications and interest in the education industry and high instruction. However, there are also situations in which they have the necessary qualifications and skills for the field but are simply not interested to be involved in the teaching industry.

Incompatibility with the education industry with career requirements can be the source of conflict when maintaining a career. Holland's Theory (1997) stated that the harmony between the individual and a career is the determinant for motivation, job satisfaction, achievements, productivity, and career stability. When choosing an employee, choosing the correct individual for the right job is paramount. From a human resource perspective, an academic qualification alone as the main criteria in choosing an employee is not relevant (Makhbul et.al, 2012). Therefore, in the teaching career, suitable field of study qualifications with career requirements in addition of insaniah skills, competency, and good character should be hand-in-hand to ensure a quality teaching career.

Seeing the conflict in choosing teaching as a career path, research on the factors that influence choosing a teaching career as an occupation among the UTM Education Faculty reveals that a majority of them chose to be educators due to interest in being a teacher and an affinity to contribute service and expertise to students and the community. Other than that, advantages in a teaching career also influenced their choice to be teachers.

Similarly, research conducted at the Faculty of Education in Universiti Teknologi Malaysia by Abdul Rahim Hamdan, Ahmad Johari Sihes, Jamaludin Ramli and Rosliza Hamzah on 'Teacher's Perception on the Current Teaching Profession' found that there is a lack of readiness in teachers with a family to move or teach in rural areas as an important factor that should be scrutinized in the recruitment process or during studies in teaching institutions or even higher learning education centers.

This problem is well-linked to the challenges in balancing requirements of offering the curriculum discussed above. The challenge before this was to see it from a students' academic development perspective while this challenge is to see it from the perspective of field of teaching. It is not simple to create teachers who are able to teach three separate fields. It is not similar as three different subjects. This is because each field of teaching requires its own skills and professionalism. This matter is explicit in the teaching field of diniah and academic.

Educational institutions can analyze the requirements of teacher education and use a multitude of sources to reanalyze and identify the requirements to teach. Among them are to reevaluate the teacher education programmes, from the viewpoint of problems and requirements, looking at developmental trends in communities, surrounding population demographic structures, and their education habits. Teacher education quality does not only depend on their qualifications alone, but also depends on their experience and knowledge while planning and executing the course.

\section{Unsuitability of Pay Rate with The Study Levels}

In general, the payroll system in maahad tahfiz has no specific standard. It largely depends on the financial capability of the school. A rough salary figure given to a teacher is between $\mathrm{RM} 1,100$ and $\mathrm{RM} 1,500$ a month without taking into consideration their qualifications. However, there are some maahads that determine their salary based on qualifications. For example, a degree holder could earn RM1,500, a diploma holder could earn RM1,300, and a certificate holder RM900 with some annual increments. Some schools have an extended increment system. However, maahad management may consider additional salary if the teachers have previous experience. Minimal salary for teachers is between RM800 and 
RM1,100. Other schools may offer around RM1,700 for certificate and diploma holders for a starting salary. Almost $40 \%$ of maahad tahfiz do not contribute to EPF and SOCSO for teachers and staff due to the high cost even though plenty of effort has been made by JAIS and PITAS by conducting courses and seminars related to the obligations of contributing to the welfare of the teachers. A few maahads take good care of the welfare of their teachers such as providing accommodation, food, takaful, umrah packages and holidays, as well as personal loans without interest.

Not all teachers involved in the process of teaching are appointed legally under the supervision of the Malaysian Ministry of Education. A number of them are only specially appointed teachers or are by contractual school appointments, and registered as contract workers in a specified timeline by agencies, private institutions, or certain organizational bodies. The majority of these teachers are knowledgeable in the related fields but do not possess the training or special teacher qualifications as those teachers under the Education Ministry. This group seems to be in line with the first group of at-risk workers, which are agency workers and temporary workers just as stated by Osman (2011) in this study on quality of work.

These bands of temporary workers are taken to work by employers as a means to sustain or fulfill a need that cannot be carried by permanent employees. As their qualifications and mastery are not up to par as permanent workers, therefore their salary will also not be the same. It is also easier to terminate them if and when their services are no longer required. Just as other contract workers, temporary teachers and those alike will almost always most likely receive a lower salary rate and lesser benefits even though their job scope and responsibilities between them and permanent workers are similar.

Research findings by Nadzri, et. al (2015) explain how the most crucial factor that influence career selection conflicts include the difficulty in finding work opportunities. Job seeking among graduates is not uniformed. Some begin their job seeking before they finish their studies even though they come from a solid and dependable family background. Conversely, there are those who are not actively seeking out a position well after graduation even though they come from a less affluent background. There are those who have already secured employment but are still on the lookout for other opportunities as the training they have received does not match their interests and personality. Other than that, a field of study that has no correlation with the career could also create conflict in choosing and sustaining a career.

Teaching requires ample sacrifice, but to be an educator can be seen as advantageous as the position of educator is not only highly regarded by the community, but their career position as a government servant is more secure without a risk of termination even if the country is facing economic difficulties. Other than that, parental influence, environmental surroundings as well as benefits or salary play an important role in their choosing teaching as a career (Azlan \& Noridah, 2010).

Minimum teacher's salary requirements for the professional management group under the service scheme for teachers who hold a degree are RM2,188.00. Based on the salary rate, a gap can be seen in the salary rate between governmental and private institutions. This difference does not yet take into account basic allowances, permanent position status, and pension as well as other facilities provided. In the context of minimum wage based on the Dokumen Pelaksanaan Perintah Gaji Minumum for workers in Peninsular Malaysia, Ministry of Human Resources set the minimum wage at RM900.00 a month. Based on this rate, 
teachers who hold a maahad tahfiz certificate receive a wage rate that is almost at the minimum wage set and is akin to unskilled foreign labour workers.

\section{Summary and Recommendations}

Based on the discussion above, it can be summarized that there are four main challenged in the requirements and qualifications for teachers in private maahad tahfiz which are low levels of teacher education, the difficulty in fulfilling teacher requirement following the student curriculum offered, imbalance in the requirement of the teaching field and teachers' field of study, and unequal pay rate with the level of qualifications obtained by teachers.

The challenges faced are not something new as with high determination and commitment from institution owners, a number of these obstacles can be overcomes with the help from the community including parents. At the same time, policy changes from the government have helped pave the way for the institutions.

To help resolve the challenges above, the author recommends some actions to the authoritative parties:

i. A professional training facility mechanism and a more systematic teacher education should be developed for maahad tahfiz teachers

ii. A teacher qualification recognition project based on their experiences should also be developed so they may be given due economic value

iii. Help from the education ministry and state government specifically in the aspect of academic subject development for students and learning aids

iv. The problem of teaching requirements, teacher education, and wage rate can be solved if there is a system to combine human resources among the maahad owners.

\section{Conclusion}

In conclusion, as an educational institution free of governmental procedures, the federation of maahad tahfiz should have their own ability and strength to be independent to ensure the sustainability of their education process. Teacher planning aspect is a major facet and it is highly competent in the human resources process, what more in the education industry that gives its main focus to the production of human resources. Success begins from the planning of requirements until their recruitment of those who are truly qualified is the most crucial decision for the institution. If not, the commitment and sacrifice founded by the previous educational institution founder will not go far and they will only be able to gain the satisfaction of fulfilling their own life careers.

\section{Reference}

Abdullah, A. H., \& Safazilah, N. (2016). Sistem Pengajaran dan Pembelajaran Tahfiz Al-Quran Darul Ta'lim, Kg. Tengah, Kluang. Dlm. Memperkasa Generasi Penghafaz Al-Quran. Oleh Mohd Yakub \& Nordin Ahmad. International SymposiumTahfiz Al-Quran Paper Proceeding 2016. Selangor: Darul Quran Jakim in collaboration with Centre of Quranic Research, Universiti Malaya.

Aminuddin, M. (1999). Human Resources Management. Kuala Lumpur: Penerbit Fajar Bakti. Azlan, N., \& Noridah, R. (2010) Faktor-Faktor Yang Mempengaruhi Pemilihan Kerjaya Perguruan Di Kalangan Pelajar-Pelajar Fakulti Pendidikan, Thesis Master, Universiti Teknologi Malaysia, Malaysia. 
Dunlap, W. P., \& Frank, D. (1996). Teacher Education for Today and Tomorrow: General and Special Education. The College Journal. 30, 97-104.

Ghani, A. R. (2016). Pembangunan Sistem Pendidikan Guru Tahfiz Di Malaysia Ke Arah Melahirkan Tenaga Kerja Terlatih. In Memperkasa Generasi Penghafaz Al-Quran.Darul Quran JAKIM: Selangor.

Holland, J. L. (1997). Making vocational choices: $A$ theory of vocational personalities and work environments (3rd ed.). Odessa, Florida: Psychological Assessment Resources.

Husin, Z. (2019) Interview. (Selangor Tahfiz Institute Association Secretary (PITAS).15 October 2018 \& 13 July 2019. Bangi, Selangor.

Sekolah, J. N. (2001). Standard Kualiti Pendidikan Malaysia. Putrajaya: Kementerian Pendidikan Malaysia.

Makhbul, Z. M., Yussof, I., \& Awang, A. H. (2012). Kriteria Pengambilan dan Pemilihan Graduan dari Perspektif Pengurusan Sumber Manusia. Student Personal Journal. 15: 1-11.

Naginder, K. (2005). Proses Evolusi Seorang Guru. Intellect Journal, 3(1), 1-89.

Noh, S. M. (2002). Perkembangan Kerjaya: Teori \& Praktis. Selangor: Universiti Putra Malaysia Publisher

Osman, Z. (2011). Kualiti Pekerjaan dan Indikator Pekerja Vulnerable. $6^{\text {th }}$ Malaysian Economy National Conference Proceeding; Ekonomi Berpendapatan Tinggi: Transformasi ke Arah Peningkatan Inovasi, Produktiviti dan Kualiti Hidup. Melaka. 5-7 June 2011. 368-376.

Richardson, A. R. (2008). An Examination of Teacher Qualifications and Student Achievement in Mathematics. Masters Dissertation. Alabama: Auburn University.

Saleh, M. H. (2020). Comparative study on the science of qira'at in higher education institutions in Malaysia, Thesis Master. Kulliyah of Islamic Revealed Knowledge and Heritage, International Islamic University Malaysia, Malaysia.

Samad, S. A. (2019). Interview. (Selangor Tahfiz Institute Association Deputy Chairman (PITAS). 19 January 2019. Kelang, Selangor.

Sava, S. (2012). Needs: Theoretical Considerations In Needs Analysis and Programme Planning in Adult Education. Opladen. Berlin: Toronto: Verlag Barbara Budrich.

Schaffner, E., \& Schiefele, U. (2007). The Effect of Experimental Manipulation of Student Motivation on The Situational Representation of Text. Jurnal of Learning and Instruction, 17(6), 755-772.

Siraj, S., \& Ibrahim, M. S. (2012). Standard Kompetensi Guru Malaysia. Education Faculty, Universiti Malaya, Malaysia.

Siraj, S., Abdullah, M. T. L., \& Sakika, K. A. (2017). Aplikasi Kaedah Interpretetive Structural Modeling Untuk Pembinaan Model Implementasi M-Pembelajaran Latihan Perguruan. JuKu; Jurnal Kurikulum \& Pengajaran Asia Pasifik. 5(4), 38-47.

Suliman, A., Yunus, M. M., \& Nor, M .Y. (2018). Experience or Training: Which Matter More in Teaching the Literature Component?. JuKu: Jurnal Kurikulum \& Pengajaran Asia Pasifik. 6(2), 2-51

Thoonan, E. E. J., Sleegers, P. F. C., Ooort, F. J., Peetsma, T. T. D., \& Geisel, F. P. (2011). How to Improve Teaching Parctices: The Role of Teacher Motivation, Organizational Factors \& Leadership Practices. Educational Administration Quarterly. 47(3), 496-536 